Available online at https://jurnal.stmikroyal.ac.id/index.php/jurdimas

\title{
INTERNET SEHAT DALAM MEDIA KOMUNIKASI DAN INFORMASI PADA SEKRETARIAT LEPPAS KABUPATEN ASAHAN
}

\author{
Fauriatun Helmiah $^{1 *}$, Dewi Maharani ${ }^{1}$, Santoso $^{1}$ \\ ${ }^{1}$ Manajemen Informatika, Sekolah Tinggi Manajemen Informatika dan Komputer Royal \\ email: *fauriatunh@gmail.com
}

\begin{abstract}
The development of Information Technology and communication which is increasingly fast is marked by the presence of internet media which has made it easier for humans to disseminate and receive/search for information without being bound by national borders in the international sphere. Humans are already living in practicality considering that increasingly modern means of communication to support all activities are available, even though the presence of the internet media can provide a variety of data, ranging from politics, economics, social, culture and so on, simply through search engines then information what is needed will be obtained. Even though the internet, information for personal life can be obtained such as health, recreation, hobbies, personal development, spiritual, and others. But there is another part that needs to be understood that the presence of internet media with offers or choices of various sites with freedom of access such as the double-edged sword, on the one hand, can bring positive impacts and on the other hand negative impacts. There are cases of defamation, insults, defamation, bullying, kidnapping, SARA issues, provocation, propaganda, hate speech, hoaxes, and the like.
\end{abstract}

Keywords: healthy internet; communication and information; media

\begin{abstract}
Abstrak: Perkembangan Teknologi Informasi dan komunkasi yang semakin cepat ditandai dengan kehadiran media internet yang telah mempermudah manusia untuk menyebarluaskan dan menerima/mencari informasi tanpa terikat batas negara dalam lingkup internasional. Kini manusia sudah hidup dalam kepraktisan mengingat sarana komunikasi semakin modern sebagai penunjang segala kegiatan telah tersedia, bahka kehadiran media internet mampu menyediakan data berbagai ragam informasi, mulai dari politik, ekonomi, social, budaya dan sebagainya cukup melalui search engine (mesin pencari) maka informasi yang dibutuhkan akan didapatkan. Bahkan melalui internet, informasi untuk kehidupan pribadi bisa diperoleh seperti kesehatan, rekreasi, hobi, pengembangan pribadi, rohani dan lainnya. Tetapi ada bagian lain yang perlu dipahami bahwa kehadiran media internet dengan tawaran atau pilihan beragam situs dengan keleluasaan akses seperti pedang bermata dua, di satu sisi bisa membawa dampak positif dan di sisi lain berdampak negatif. Terjadi kasus penistaan, penghinaan, pencemaran nama baik, bullying (perundungan), penculikan, isu SARA, Provokasi, propaganda, ujaran kebencian, berita bohong (hoax) dan sejenisnya.
\end{abstract}

Kata kunci: internet sehat; komunikasi dan informasi; media 
Available online at https://jurnal.stmikroyal.ac.id/index.php/jurdimas

\section{PENDAHULUAN}

Pertumbuhan pengguna internet di Indonesia meningkat setiap tahunnya dan diantaranya adalah remaja berusia 15-19 tahun. Layanan yang paling banyak digunakan oleh pengguna internet di Indonesia yaitu: instant messaging, E-mail dan social network. Dari perkembangan internet ini kita bisa mendapatkan berbagai nilai positif, yaitu memudahkan kehidupan manusia dalam berkomunikasi dan mencari informasi namun terdapat pula sisi negative yang memilik dampak buruk bagi individu maupun kelompok yang tidak hanya merugikan secara material tetapi juga mental. Sisi negative internet antara lain cyberbullying, cybercrime, gambling, pornografi, penipuan online dan lain sebagainya

Internet sehat dan aman (INSAN) adalah suatu program dari pemerintah Indonesia yang pernah dicanangkan oleh Kementerian Komunikasi dan Informatika Indonesia (Kemkominfo) pada tahun 2015 dengan tujuan mensosialisasikan penggunaan internet secara sehat dan aman melalui pembelajaran etika berinternet secara sehat dengan melibatkan seluruh komponen masyarakat. (Hidayanto, 2015).

Seiring waktu berjalan pengguna internet saat ini bukan hanya kalangan remaja saja namun usia balita karena pada masa sekarang ini para orang tua membiasakan anaknya menggunakan gadget dan melihat video dari youtube untuk hiburan anak-anak mereka, namun tidak semua orang tua teliti dalam mengawasi anak-anaknya, hal yang paling di takutkan adalah kecenderungan melihat video yang tidak seharusnya dilihat karena tidak sesuai umur. Maka dari itu perlu edukasi bagi masyarakat dalam penggunaan internet yang sehat. (Talika, 2016) dalam penelitian nya yang berjudul manfaat internet sebagai media komunikasi bagi remaja di desa air manga kecamatan laiwui kabupaten Halmahera selatan berdasarkan hasil penelitian yang sudah dilakukan frekuensi mengenai internet membawa manfaat positit bagi para remaja, dimana 40 responden $80 \%$ menyatakan internet membawa manfaat positif bagi para remaja selaku pengguna, karena internet membantu responden dalam mengerjakan tugas-tugas. Sedangkan kadang-kadang 10 responden $20 \%$ menyatakan bahwa manfaat yang diterima tidak selalu manfaat yang positif.

Internet sangat erat kaitannya dengan media komunikasi dan informasi, pada masa sekarang ini informasi yang ada di internet sangat beragam namun tidak semua dapat disaring dengan baik, ada beberapa informasi yang berada di dunia maya tidak selalu benar lalu disebarkan oleh pengguna internet yang tidak memahaminya, pentingnya informasi yang bagikan agar tidak tejadi kegaduhan dan kesalahapahaman serta kerugian bagi pihak yang bersangkutan dengan informasi tersebut. Dampak negatif informasi yang kita sebar dan belum tentu kebenarnya akan menimbulkan ketakutan dan kepanikan serta merugikan pihak yang ada dalam informasi tersebut.

Internet sehat adalah segala sesuatu yang berkaitan dengan beraktifitas menggunakan internet yang memiliki nilai positif bagi pengguna dan bagi orang lain. manfaat internet serta dampak negatif bagi pengguna penting untuk dipahami, sehingga pengabdian ini dilakukan dengan tujuan untuk memberikan pemahaman kepada Pengurus Sekretariat Leppas tentang dampak negatif dan positif pada internet. 
Available online at https://jurnal.stmikroyal.ac.id/index.php/jurdimas

\section{METODE}

Metode Pengabdian yang
dilakukan merupakan bagian dari
pendidikan masyarakat yaitu metode
penyuluhan yang bertujuan meningkat-
kan pemahaman para pengurus
sekretariat Leppas akan besarnya dampak dari Internet Sehat. Kegiatan pengabdian kepada masyarakat ini dilaksanakan di Sekretariat Leppas yang beralamat Jl.Wr, Supratman No 2 Kisaran, Sumatera Utara pada tanggal 03 - 04 Juli 2020 , pukul $08.00 \mathrm{wib}$ s/d selesai.

Kegiatan pengabdian kepada masyarakat ini dilakukan oleh tim Dosen STMIK Royal Kisaran dan terdiri dari 21 peserta dan Tim pengabdian terdiri dari 3 orang dan semua bertindak sebagai pemateri atau narasumber. dalam kegiatan pengabdian masyarakat ini dilakukan dalam wujud penyuluhan /sosialisasi di dalam ruangan dengan menggunakan metode brainstorming, sharing, diskusi, tanya jawab. Pelatihan dibagi kedalam dua sesi yakni pemaparan materi dan sesi tanya jawab.

\section{PEMBAHASAN}

Pelaksanaan kegiatan pelatihan internet sehat dalam menggunakan media komunikasi dan informasi ini diawali dengan Pengenalan Media Internet, Sosialisasi Internet Sehat, Perkembangan Media Internet, Kaitan Penggunaan Media Internet dengan Komunikasi dan Informasi.

\section{Internet}

Komunikasi antara manusia yang diistilahkan Littlejhon dengan human commucation, kejadiannya (setting) sudah sejak lama menjadi perhatian para akademisi. Pada awalnya, setting itu diindetifikasikan Littlejhon berdasarkan empat konteks, yaitu interpersonal, groups,organization, dan mass. Konteks ini kemudian ia ralat dengan menambahnya menjadi lima konteks, yaitu dengan memasukkan konteks publics. Sejauh pada semua konteks dimaksud, kejadiannya secara relative dapat berwujud melalui penggunaan media parsial. Namun, dengan medium internet sebagai produk konvergensi teknologi informasi dan komunikasi, semua konteksd tersebut jadi dimungkinkan dapat berlangsung. Kemampuan medium internet yang demikian fenomenal menyebabkannya mendapat banyak peristilahan. Diantaranya ada yang menyebut media baru, media modern, media inkonvensional, telematika, dan ada pula yang menggelarinya dengan supermedium for communicating (Hidayanto, 2015).

\section{Internet Sehat}

Internet sehat merupakan upaya atau ajakan kepada masyarakat pengguna internet untuk memanfaatkan internet untuk hal-hal positif. Internet tidak bisa lepas dari sisi negative dan positif (Nur, 2018). Perilaku menggunakan media informasi berbasis internet berkaitan erat dengan sedikit banyak materi negatif. Semakin waspada dan tidak ceroboh dalam menggunakan internet, maka akan memperkecil kemungkinan terpengaruh berbagai materi negatif dari internet. Untuk itu diperlukan penggunaan internet secara sehat. (Darmawan, Lestari, \& Wibawati, 2019)

\section{Teknologi Informasi dan Komunikasi}

Teknologi Informasi dan Komunikasi adalah paling besar terminology yang mencakup seluruh peralatan teknis untuk memproses dan menyampaikan informasi. Teknologi informasi dan komunikasi mencakup dua aspek yaitu 
Available online at https://jurnal.stmikroyal.ac.id/index.php/jurdimas

teknolgi informasi dan teknologi komunikasi. Teknologi informasi meliputi segala hal yang berkaitan dengan proses, penggunaan sebagai alat bantu, manipulasi, dan pengelolaan informasi. Sedangkan teknologi komunikasi adalah segala sesuatu yang berkaitan dengan penggunaan alat bantu untuk memproses dan mentransfer data dari perangkat yang satu ke lainnya (Darimi, 2017). Oleh karena itu, teknologi informasi dan teknologi komunikasi adalah dua buah konsep yang tidak terpisahkan. Jadi Teknologi Informasi dan Komunikasi mengandung pengertian luas yaitu segala kegiatan yang terkait dengan pemrosesan, manipulasi, pengelolaan, pemindahan informasi. (Budiman, 2017)

\section{Pengguna Internet}

Data dari Kemkominfo pada Agustus tahun 2019 di Indonesia, pengguna internet mencapai 150 juta jiwa dengan penetrasi $56 \%$ yang tersebar diseluruh wilayah. Jumlah tersebut hanya selisih sedikit dengan jumlah pengguna internet mobile yang berjumlah 142.8 juta jiwa dengan perentase penetrasi $53 \%$.

\section{Tingkat Pengguna Internet Aktif Indonesia}

Di dalam aktivitas penggunaan media internet menurut sumber dari Hootsuite pengguna aktif media social memiliki penetrasi sebesar 1500 juta jiwa atau sama dengan $56 \%$ dan pengguna aktif media social mobile memiliki penetrasi 1428 juta jiwa atau sama dengan $53 \%$.

Hasil Survey yang dilakukan APJII pada tahun 2018 pengguna internet di Indonesia memiliki perentase paling tinggi di daerah pulau Jawa dan pulau Sumatera.

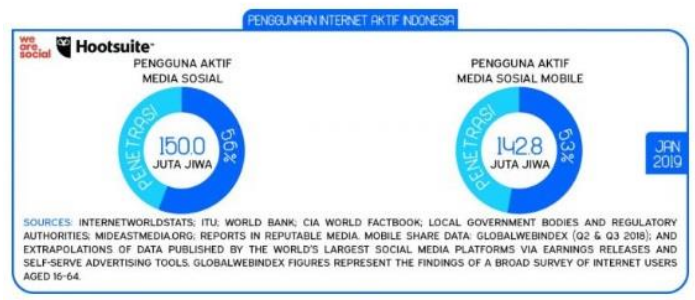

Gambar 1. Pengguna Internet Aktif Indonesia

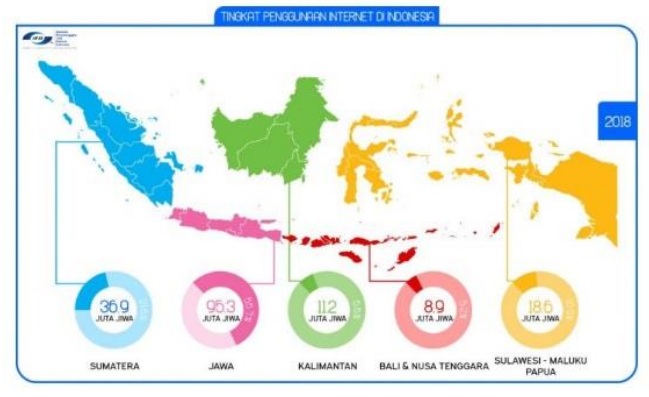

Gambar 2. Tingkat Pengguna Internet di Indonesia

\section{Manfaat Internet}

1. Kemudahan dalam mencari informasi

2. Flexibilitas

3. Mudah digunakan

\section{Resiko Keamanan :}

1. Kerahasiaan

2. Integritas

3. Keaslian

4. Ketersediaan

Tips Internet sehat dan aman kepada pengguna

1. Waspadai Virus: Malware, Adware, Spyware. Jangan sembarang unduh file dan baca petunjuk instalasi aplikasi/software. (Pasang Antivirus dan AntiMalware dikomputer)

2. Batasi informasi yang bersifat pribadi (data keluarga, alamat, dll).

3. Pastikan foto/video yang diposting tidak akan merugikan diri sendiri atau orang lain. 
Available online at https://jurnal.stmikroyal.ac.id/index.php/jurdimas

4. Jangan merespon e-mail dari pengirim yang tidak dikenal (spam) dan jangan membuka link yang diberikannya.

5. Segala sesuatu yang bersifat pribadi lebih baik tidak dipublikasikan di halaman yang bisa diakses umum.

6. Jangan mengakses konten illegal, seperti pornografi, perjudian, rasisme, pelecehan SARA.(Winarso, Syahril, Aryanto, Arribe, \& Diansyah, 2017)

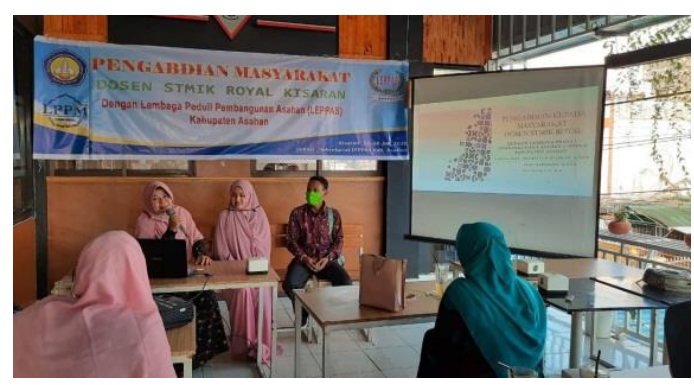

Gambar 3. Penyuluhan Narasumber

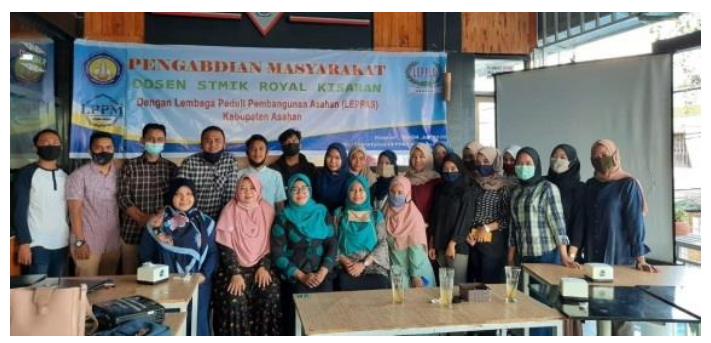

Gambar 4. Foto Bersama Seluruh Peserta

\section{SIMPULAN}

Berdasarkan pelaksanaan kegiatan Pengabdian kepada Masyarakat yang telah dilakukan dapat disimpulkan Dampak negatif pada pengguna internet menjadi masalah kita bersama maka perlu adanya sosialisasi penggunaan internet yang sehat, salah satu cara adalahdengan mengedukasi peserta dalam penggunaan internet dengan baik.

\section{DAFTAR PUSTAKA}

Budiman, H. (2017). Peran Teknologi Informasi Dan Komunikasi Dalam Pendidikan. $A l$ Tadzkiyyah: Jurnal Pendidikan Islam, 8(I), 31-43.

Darimi, I. (2017). Information And Communication Technologies Sebagai Media Pembelajaran Pendidikan Agama Islam Efektif Era Teknologi Informasi. Cyberspace: Jurnal Pendidikan Teknologi Informasi, 1(2), 111121.http://dx.doi.org/10.22373/cs. v1i2.2030.

Darmawan, A., Lestari, M., \& Wibawati, Y. (2019). Sosialisasi Penggunaan Internet Sehat bagi Remaja Karang Taruna. Jurnal PkM Pengabdian Kepada Masyarakat, 2(2), 71. Retrieved from http://dx.doi.org/10.30998/jurnalp km.v2i02.3011.

Hidayanto, F. (2015). Pentingnya Internet Sehat. Asian Journal of Innovation and Entrepreneurship, 4(01), 21-24.

Lubis, I. A., Aulia, R., \& Yuma, F. M. (2019). Peningkatan Pemanfatan Peran Teknologi Informasi Bagi Masyarakat Sekitar Polsek Porsea Kab. Toba Samosir. Jurdimas Royal, 2(2), 175-178.

Nasution, D., Rahayu, E., \& Rohminatin, R. (2019). Internet sehat dan aman (insan). Jurdimas Royal, 2(2), 179-182.

Nur, L. (2018). Gambaran Penggunaan Internet dalam Mencari Informasi Kesehatan Pada Siswa Sekolah Menengah Pertama (SMP) X. Jurnal Promkes: The Indonesian Journal of Health Promotion and Health Education, 6(2), 188-200.

Talika, F. T. (2016). Manfaat Internet 
Jurdimas (Jurnal Pengabdian Kepada Masyarakat) Royal

Vol. 4 No. 1, Januari 2021, hlm. 71 - 76

Available online at https://jurnal.stmikroyal.ac.id/index.php/jurdimas

Sebagai Media Komunikasi Bagi

Remaja Di Desa Air Mangga

Kecamatan Laiwui Kabupaten

Halmahera Selatan. ACTA

DIURNA KOMUNIKASI, 5(1).

Winarso, D., Syahril, S., Aryanto, A., Arribe, E., \& Diansyah, R.
(2017). Pemanfaatan Internet

Sehat Menuju Kehidupan

Berkemajuan. Jurnal Pengabdian

UntukMu NegeRI, 1(1), 19-23.

Retrieved

from

https://doi.org/10.37859/jpumri.v

$1 \mathrm{i} 1.29$ 